\title{
The development and structural confirmation of an instrument for measuring the social responsibility of small and micro business in the African context
}

\author{
Dennis Yao Dzansi and Marius Pretorius
}

\begin{abstract}
Purpose - The purpose of this paper is to propose an instrument, the Small Enterprise Social Responsibility Inventory (SESRI) for measuring business social responsibility (BSR) in the African venture setting.

Design/methodologylapproach - The approach was to use the components of Dzansi's framework to create an instrument for measuring BSR activities of small ventures that operate in rural Africa. The instrument was tested in a rural community in South Africa for validity reliability structure, and its ability to predict firm performance given performance of certain BSR activities.

Findings - Through factor analysis of data obtained from 314 small businesses in a rural South African setting, the instrument was found to be valid for measuring small business BSR and identified five factors: expected benefits; community or customer practices; realised or actual benefits; awareness or attitude and performance; and employee practices. Through discriminant analysis, employee practice was found useful for classifying ventures as high or low sales and profit performers, suggesting that information on a firm's BSR related employee practices may be useful predictors of sales and profit. Research limitations/implications - Firstly, the methodology requires self-evaluation by the respondents. However, those respondents who reported low levels of BSR activities (and negative growth in sales and performance) also reflected on their own "performance" and recorded it as low signifying some level of realistic reporting. Secondly, there is absence of question items about environmental issues. Thirdly, the sample was taken in a small rural setting, which requires caution when generalising from the results.

Originality/value - This study provides an African context specific measurement instrument for addressing small business BSR. Academics will find it useful in their research efforts. Fund managers will also find it useful for evaluating small business BSR performance. Owners/managers will have a benchmark in performing their social obligations.
\end{abstract}

Keywords Social responsibility, Corporate social responsibility, Customer orientation, Employees, Stakeholder analysis, Africa

Paper type General review

\section{Introduction}

As Turker (2008) alludes to, the role of business in society is not new. Carroll (1979) traced its emergence to the 1930s. However, the heightened prominence that the concept of Business Social Responsibility (BSR), variously referred to as Corporate Social Responsibility (CSR), Corporate Social Investment (CSI), Corporate Social Performance (CSP), Corporate Citizenship (CC) and so on, has attained in recent times comes amidst growing concerns that, while businesses bring progress to society, their actions more often than not, produce negative externalities that are unintended and need to be repudiated. The fact that these externalities accrue to societies who are not party to the economic decisions of businesses that bring them into being, makes it imperative that "victims" are rewarded and perpetrators take responsibility and provide means to at least minimise their impact. Business Social Responsibility (henceforth referred to as BSR) can be seen as a way of "compensating" society for the 
hardships endured. In this sense, it is fair to say that BSR (2001) has a strong social focus.

While the social purpose of BSR has dominated the BSR agenda and has been well explored - even if inconclusively, there appears to be a changing mindset that BSR engagement can also enhance business performance. Empirical evidence by researchers including Wingard (2001) suggest that, being perceived as socially responsible can actually enhance overall business performance. Thus, backed by empirical evidence - albeit inconclusively, BSR has gradually assumed two dimensions - societal and financial. This means that any measurement instrument for addressing BSR must capture the societal and financial aspects. Our instrument is designed to measure a firm's focus on social responsibility performance as well as the benefits that accrue to both business and society.

No society, region, country, or continent can be regarded as immune to the negative impacts of business. In respect to Africa, Kapelus (2007, p. 13) observes, "Companies have a long history of being deeply involved in the lives of African communities... Business impacts have been both positive and negative". In a remote area of South Africa that is not far from the research locale, the effects of the activities of a firm that mined asbestos are being felt in devastating proportions, many years after the firm ceased operations. Considering this and many other such cases, it is only fair to demand that businesses that operate in Africa, especially in rural areas where business activities are likely to be unmonitored due to accessibility problems, must take BSR seriously.

Although much has been written on the society versus business relation, one easily notices that BSR in the African context remains under explored. Thus, questions such as what are the most likely BSR activities for smaller businesses that operate in Africa or how do smaller businesses that operate in Africa perceive and apply BSR just to mention a few, remain unanswered. Visser (2007) makes the important point that compared to other regions, Africa lags far behind in respect to small business BSR research. This is probably because of the absence of measurement instruments that capture the essence of small business BSR in the African context.

Yet in Western countries such as Canada, UK, and the USA, numerous empirical researches have been done on the small business/BSR interface. In these countries, context specific frameworks and measurement instruments exist that guide their social responsibility research agenda. For example in Spain, there is what is called the Catalan social responsibility framework for small businesses. Unfortunately, these foreign frameworks may not be helpful in the African context. Visser (2007) provides many plausible reasons for this. These include: different cultures affect how consumers expect businesses to behave; the BSR agenda challenges of developing countries are different from those of the developed world; existing measurement instruments produced by the developed country researches do not take the African contexts into consideration; and European and American metrics are unsuitable for Africa because customs and beliefs dictate what activities businesses are likely to engage in. Consequently, there is need to develop metrics applicable to the African context.

Using a theoretical model of small business BSR that is based on stakeholder theory, this research sought to develop and validate an instrument for measuring BSR in small businesses in the African context. The conceptual framework which is based on Dzansi's (2004) model was validated by primary data drawn from 314 small businesses in the Greater Taung Local Municipality (GTLM), a rural part of South Africa.

Although South Africa bears some features of the developed world, most of the rural areas remain characteristically similar to those of other African countries particularly those countries that lie South of the Sahara. There is no doubt that customs and needs of African rural communities are identical in many ways. For example the concept of "Ubuntu" which means - caring for one another is not akin to only South Africa. Writers (e.g. Dzansi, 2004), have acknowledged the pervasive nature of "Ubuntu" across Africa. We therefore consider any rural location in South Africa a suitable representation of the rural African context.

\section{Research objectives}

The primary objective of this study is to use the dimensions, elements, and outcomes of BSR relevant for small ventures from the literature as illustrated in Dzansi's (2004) framework to

construct and test an instrument for measuring BSR in the African venture setting. The subsidiary objectives are to aid small businesses in Africa in the selection of affordable BSR best practices and to facilitate greater understanding of the concept of BSR.

The paper is structured as follows: It begins by exploring the concept of BSR by firstly examining some key definitions of BSR and the meanings that they espouse, culminating in a working definition. A working definition is imperative because of the plethora of definitions that exist for the concept. Thereafter, we describe the main features of the theoretical framework including the dimensions, elements and the specific items. We follow by describing the empirical investigation, including the statistical tests performed, and then present the results of the statistical analysis. We conclude with a discussion of the implications of the results and limitations, and suggest issues for future 
research.

\section{Conceptualising BSR for measurement}

The literature search reveals numerous definitions for BSR. However, for the purpose of this study, the following were chosen for discussion so as to capture its essence:

Business's obligation to seek socially beneficial results along with economically beneficial results in its policies, decisions and actions (Kyambalesa, 1994).

The continuing commitment by business to behave ethically and contribute to economic development while improving the quality of life of the workforce and their families as well as of the local community and society at large (World Business Council for Sustainable Development (WBCSD), 2001).

A company's commitment to operating in an economically and environmentally sustainable manner while recognising the interest of its stakeholders. Stakeholders include investors, customers, employees, business partners, local communities, the environment, and society at large (Peyton, 2003).

A concept which encourages organisations to consider the interest of society by taking responsibility for the impact of its activities on customers, employees, shareholders, communities and environment in all aspects of its operations (Centre of Strategic Research and Development of Georgia, 2007).

Examination of these definitions reveals that in pursuing the interest of owners, managers must never forget the needs of other interested parties (stakeholders) because these people are capable of impacting directly or indirectly on business bottom-line. For example, workers need to be treated in a humane and fair manner; customers need to be satisfied; and the well being of the communities in which business is conducted need to be taken care of; all of these actions done over and above normal legal requirements.

Considering the above and the fact that South African businesses have a long history of nstituting BSR programs on discretionary basis (Irwin, 2003:2), this study operationally defines BSR as:

... a firm's commitment to operating in an economically sustainable manner while at the same time recognising the interests of its other stakeholders (customers, employees, business partners, local communities, society at large) over and above what the law prescribes.

In essence, this definition recognises discretionary responsibilities, one of Carroll's (1979) four social responsibility categories as the "true BSR". By this definition, we agree with Sims (2003); Davis (1973); and McGuire (1963) who all argued at different times that BSR and the other responsibilities as espoused by Carroll (1979) are not the same thing. This means the exclusion of mandatory activities (ethical, legal, and economic categories) of Carroll's (1979) social performance model. Our view is that merely complying with laws and regulations and conducting business in an ethical manner, while protecting the interest of owners is not sufficient for a firm to be regarded as being socially responsible. Our definition also implies a stakeholder emphasis and thus identifies with Donaldson and Preston (1995, p. 2) who define stakeholders as "those groups without whose support the organisation will cease to exist".

According to Laczniak and Murphy (1993, p. 2), a firm's stakeholders can be classified as primary or secondary. These authors regard groups or people without whose continuing participation a business cannot continue for any reasonable period of time as primary stakeholders. According to Dzansi (2004, p. 2), typical primary stakeholders of a firm with whom the firm has high interdependence include shareholders, financiers, customers,

employees, government, and communities that provide infrastructure and markets. On the other hand, Laczniak and Murphy (1993, p. 2) call those groups or people who have the capacity to influence or are affected by the business but who are not engaged in transactions with it and are not essential to its survival as secondary stakeholders. Such groups include the media and other civil societies that are capable of putting pressure on business.

Today, several measures exist to evaluate BSR (Turker, 2009). Some of the famous ones include Bragdon and Marlin (1972), Aupperle (1984), Freedman and Jaggi (1982), Chen and Metcalf (1984), Davidson and Worrell (1990), Baucus and Baucus (1997), Ruf et al. (1998), Maigan and Ferrell (2000), and Quazi and O'Brien (2000) and quite recently, Turker (2009). Examination of these instruments shows that they are either designed for use in corporate business or by small businesses in the Western world. The problem is that these instruments are sometimes used by researchers without regard to size and context in spite of Carroll's (1979, p. 501) advice that in developing a conceptual framework for BSR, one must identify social or topical issues to which responsibilities of particular businesses are tied. The argument follows that because of resource limitations, small business will focus their BSR activities on those primary stakeholders closest to them. In this study, the opinion is held that the local communities, employee and customer issues will be most vital to small businesses that operate in African communities because they are their most important and closest 
primary stakeholders.

Taking into account Carroll's (1979) concern that particular social issues are of varying interest to businesses depending on several factors, it is apparent that none of the existing instruments is really suitable for measuring BSR in small businesses in the African context.

Prompted by shortcomings in the existing instruments, Turker (2009) went on to develop the CSR Scale. While Turker's (2009) instrument went a long way to address many concerns, shortcomings still exist.

For one thing, Turker's (2009) instrument contains items that are of legal nature. We hold the view that, for an action to really be regarded as socially responsible, it must exceed the prescripts of law. Therefore, legal compliance in itself would probably not make a business socially responsible. Thus, BSR should refer to discretionary activities that are in excess of legal requirements. After all, compliance with the law is a basic requirement for a licence to operate. In other words, unlike BSR which is a choice and discretionary, obeying the law by paying tax and complying with other statutory requirements is not. Inclusion of items like paying tax, and compliance with minimum legal regulations should therefore not be a scale item for BSR.

Another problem is that, although Turker's (2009) CSR Scale contains items that are relevant to small businesses, thus being more useful to small businesses than those before it, it does not address the specific needs of most African communities. Yet, it is known that local contexts determine activities that communities value and appreciate. As Visser (2007), Weyzig (2006), Baskin (2005), Welford (2005), and Holme and Watts (2000) point out, BSR developments and activities in the developing countries differ from those of the developed countries as BSR is shaped by context specific factors (Weyzig, 2006, p. 69; Visser, 2007). Consequently, small businesses that operate in the African context cannot be expected to engage in the same activities and with the same principles as their developed country counterparts. Items like contribution to community projects such as scholarship schemes, local employment, sponsorship of churches, schools, just to mention a few, are some of the well documented basic needs of most African communities. There is therefore a gap in the literature that needs to be filled.

\section{The conceptual framework guiding the scale development}

We based the questionnaire on the framework shown in Figure 1 that consists of three aspects namely: dimensions; elements; and outcomes. The dimensions are broadly classified as: community involvement, consumerism, and employee relations. Outcomes accrue to business and other stakeholders. The benefits to the organisation are classified as tangible and intangible.

\section{Methodology and findings}

The approach of this study was to use the components of the framework described in Dzansi (2004) as summarised in Figure 1 to create an instrument for measuring BSR activities of small ventures that operate in Africa. The instrument was then tested in a rural community in South Africa for validity, reliability, and structure. Using discriminant analysis, its ability to predict firm performance, given performance of certain BSR activities, was also determined.

\section{The sample}

Data were collected from owners and managers of small ventures in the Greater Taung Local Municipality (GTLM) in the North West province of South Africa. A sample of 350 small ventures was identified and the manager or owner interviewed by four trained interviewers. A total of 314 structured questionnaires were returned and found to be usable, representing an 89.7 per cent response rate. The demographic composition of the sample is described in terms of gender, age, business age, gross profit growth and sales growth reported by the respondents (see Tables I, II and III). 
Figure 1 Components of the small, medium and miero enterprise - BSR framework

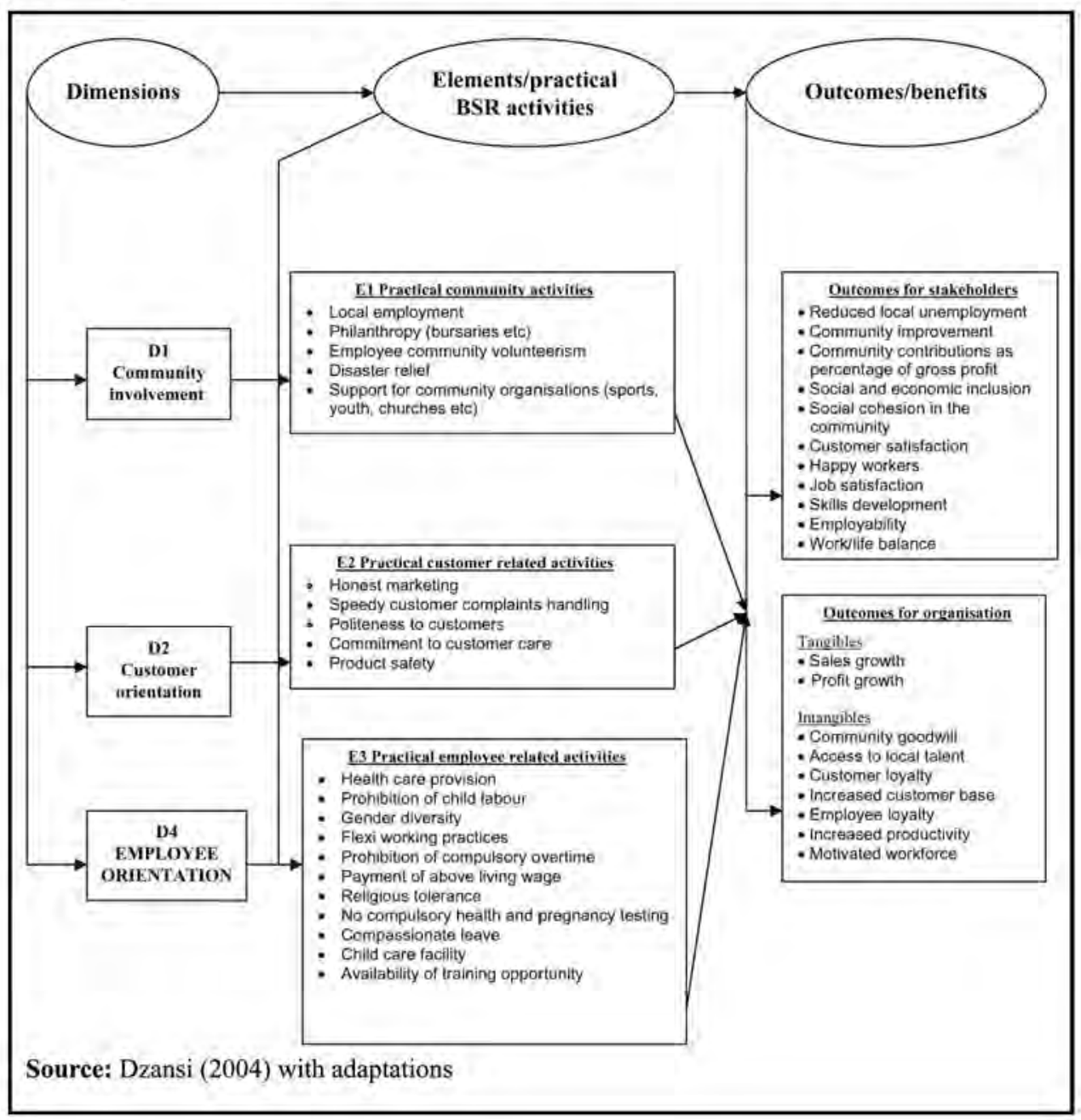

As shown in Figure 1, the key issues for the elements community, consumerism, and employee relations were identified for SMMEs. Possible outcomes and issues deemed important to each stakeholder group namely: communities, employees, and customers were identified through a review of the literature and exploratory interviews with community members, employees, and owner/managers. A full description of the framework can be found in Dzansi (2004).

\section{The instrument}

A five-point Likert scale (where $1=$ strongly disagree, $2=$ moderately disagree, $3=$ undecided, $4=$ moderately agree and 5 = strongly agree) was used to measure the opinions of respondents. The items included in the instrument to capture the dimensions of BSR are divided into six categories, namely: biographical data, community involvement, customer relations, employee relations, outcomes or benefits, and BSR awareness 
Table I Rotated factor structure for the Small, Enterprise Social Responsibility Inventory (SESRI)

\begin{tabular}{|c|c|c|c|c|c|c|c|}
\hline \multicolumn{2}{|c|}{ Question } & \multirow{2}{*}{$\begin{array}{c}\begin{array}{c}\text { Gronbach's } \\
\text { alpha }\end{array} \\
0.8716\end{array}$} & \multirow{2}{*}{$\begin{array}{c}\begin{array}{c}\text { Expected } \\
\text { benefits }\end{array} \\
0.990\end{array}$} & \multirow{2}{*}{$\begin{array}{c}\text { Community or } \\
\text { customer } \\
\text { practices }\end{array}$} & \multirow{2}{*}{$\begin{array}{c}\begin{array}{c}\text { Factor loadings } \\
\text { Realised or } \\
\text { actual } \\
\text { benefils }\end{array} \\
0000\end{array}$} & \multirow{2}{*}{$\begin{array}{c}\begin{array}{c}B S R \\
\text { performance }\end{array} \\
0.000\end{array}$} & \multirow{2}{*}{$\frac{\begin{array}{c}\text { Employee } \\
\text { praclices }\end{array}}{0.000}$} \\
\hline 25. & Keeps operating cosis down & & & & & & \\
\hline 26. & Increased level of customer loyalty & 0.8699 & 0.945 & 0.000 & 0.000 & 0.000 & 0.000 \\
\hline 28. & Employee attendance nas improved & 0.8742 & 0.851 & 0,000 & 0.000 & 0.000 & 0.000 \\
\hline 24. & Greater worker productivity & 0.8710 & 0.765 & 0.000 & 0.000 & 0.000 & 0.000 \\
\hline 23. & Increased sales & 0.8693 & 0.662 & 0.000 & 0.000 & 0.336 & 0.000 \\
\hline 13. & $\begin{array}{l}\text { The company always and clearly } \\
\text { explains the way the producl works to } \\
\text { the customer }\end{array}$ & 0.8806 & 0.000 & 0.836 & 0.000 & 0.284 & 0.000 \\
\hline 12. & $\begin{array}{l}\text { The company cannot be concerned } \\
\text { with vuinerable groups such as } \\
\text { children }\end{array}$ & 0.8801 & 0.000 & 0.630 & 0,000 & 0.000 & 0.000 \\
\hline 14. & $\begin{array}{l}\text { The company sells only clearly labelled } \\
\text { products }\end{array}$ & 0.8792 & 0.000 & 0.589 & 0.000 & 0.000 & 0.000 \\
\hline 8. & $\begin{array}{l}\text { The company provides paid matemity } \\
\text { leave }\end{array}$ & 0.8758 & 0.000 & 0.413 & 0.287 & 0.000 & 0.000 \\
\hline 19. & The concept of BSR is well known to me & 0,8717 & 0.000 & 0,407 & 0.000 & 0.000 & 0.000 \\
\hline 29. & Sales has been growing & 0.8745 & 0.330 & 0.000 & 0.397 & 0.000 & 0.000 \\
\hline 30. & $\begin{array}{l}\text { Overall financ al performance has been } \\
\text { improving }\end{array}$ & 0.8742 & 0.312 & 0.000 & 0.857 & 0.000 & 0.000 \\
\hline 31. & Increasing number of loyal customers & 0.8858 & 0.000 & 0.000 & 0.937 & 0.000 & 0.000 \\
\hline 22. & Enhanced company image & 0.8684 & 0.380 & 0.000 & 0.563 & 0.000 & 0.000 \\
\hline 20. & $\begin{array}{l}\text { Businesses irrespective of size have a } \\
\text { responsibility to contribute to the above } \\
\text { named social causes in }\end{array}$ & 0.8697 & 0.299 & 0.000 & 0.000 & 0.732 & 0.000 \\
\hline 21. & $\begin{array}{l}\text { Business irrespective of size stands to } \\
\text { benefit from contributing lowards social } \\
\text { causes }\end{array}$ & 0,8732 & 0.282 & 0,000 & 0.000 & 0.788 & 0.000 \\
\hline 11. & $\begin{array}{l}\text { The company is commilted lo Tair } \\
\text { trading praclices }\end{array}$ & 0.8790 & 0.000 & 0.000 & 0.000 & 0.467 & 0.000 \\
\hline 16. & $\begin{array}{l}\text { My company gives first preference to } \\
\text { local employment }\end{array}$ & 0.8826 & 0.000 & 0.276 & 0.000 & 0.434 & 0.000 \\
\hline 9. & $\begin{array}{l}\text { I somelimes loose my patience with } \\
\text { customers whose complaints I } \\
\text { consider wrong }\end{array}$ & 0.8842 & 0.000 & 0.552 & 0,000 & 0.407 & 0.000 \\
\hline 17. & $\begin{array}{l}\text { Workers can use company lime for } \\
\text { community issues }\end{array}$ & 0.8867 & 0.000 & 0.000 & 0000 & 0.407 & 0.000 \\
\hline 2. & $\begin{array}{l}\text { The company provides workers with } \\
\text { regular training }\end{array}$ & 0.8772 & 0.303 & 0.000 & 0.000 & 0.000 & 0.464 \\
\hline 4 & $\begin{array}{l}\text { The company provides paid family } \\
\text { sickness and bereavement leave to its } \\
\text { employees. }\end{array}$ & 0,8758 & 0.000 & 0,000 & 0.000 & 0.000 & 0.784 \\
\hline 3 & $\begin{array}{l}\text { The company provides paid malernily } \\
\text { leave }\end{array}$ & 0.8758 & 0.000 & 0.889 & 0.000 & 0.000 & 0.889 \\
\hline 5. & $\begin{array}{l}\text { Employees are iree to decide overtime } \\
\text { they like }\end{array}$ & 0.8852 & 0.000 & 0.000 & 0.000 & 0.000 & 0.855 \\
\hline
\end{tabular}




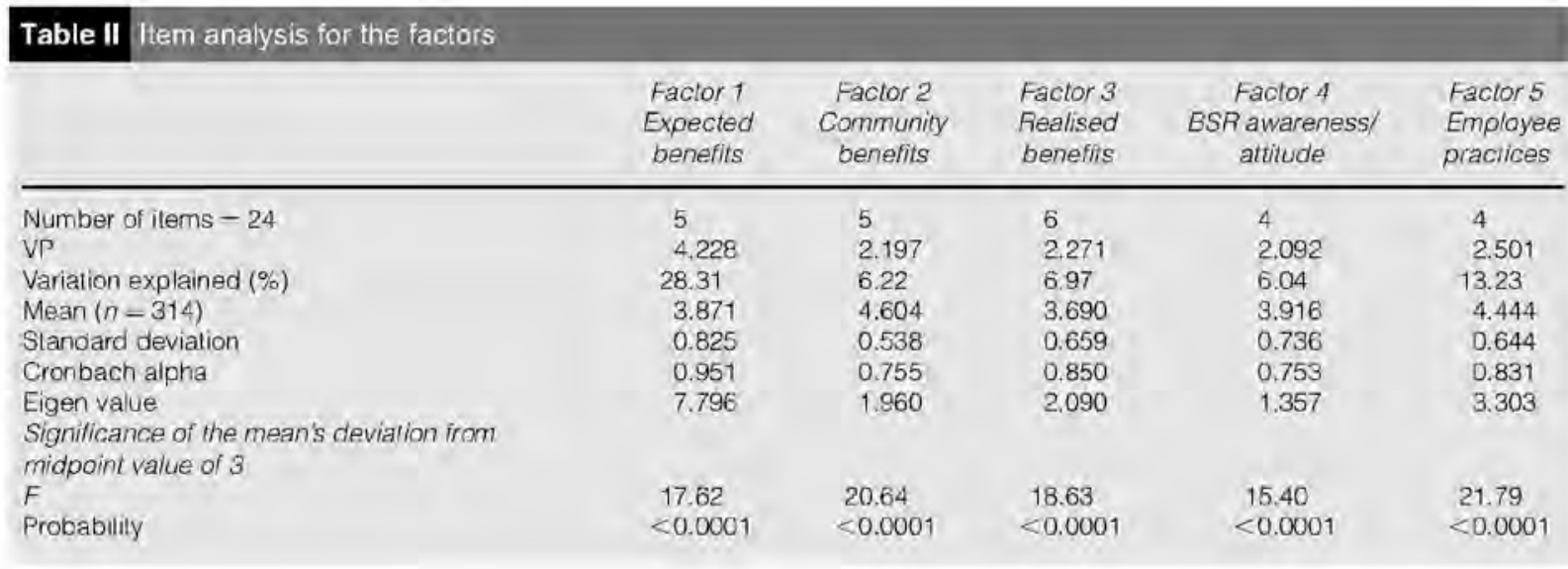

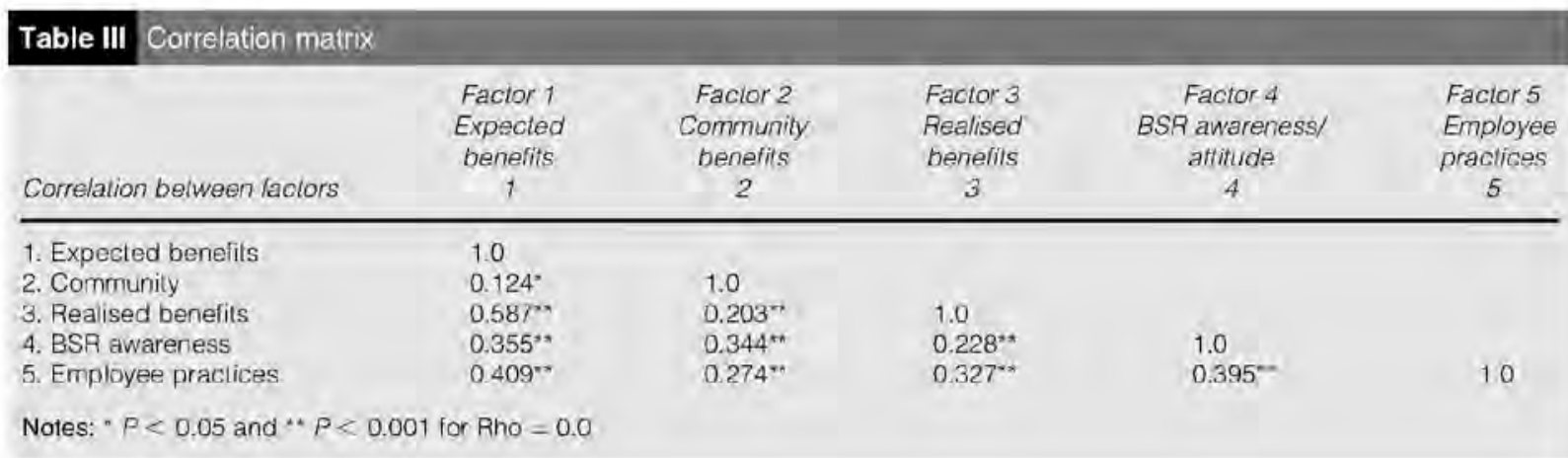

Developing the measurement instrument involved operationalising the variables identified in the literature for measurement, ensuring reliability and validity, pre-testing of a draft questionnaire, factor analysis and discriminant analysis. The linguistic meaning of BSR was operationalised into observable indicators in order for it to be measurable. In this regard and based on the literature reported earlier, Sekaran's (1992, p. 152) method (see Figure 1) that involves the breaking down of a concept into dimensions and eventually into measurable elements was employed. The elements were used to compile the questionnaire items.

The biographical items collected included information on type of business, gender of respondent, age of respondent, educational level of respondent, number of years the business had been in operation, ethnicity of owner/manager as measured by first language, sales growth, gross profit growth, number of employees, and amount contributed towards BSR activities measured as a percentage of pre-tax profit. The sample units were selected using simple random sampling.

The questions on community involvement required respondents to indicate whether or not they contributed to certain community causes, and to indicate the amount of money (expressed as a percentage of pre-tax profit) spent on social causes.

For customer relations issues, questions relate to how promptly respondents reacted to their customer complaints, how politely they dealt with customers, how honest they were in their marketing, and most importantly how committed they were to customer satisfaction. These elements that are important to win and retain a loyal customer base are crucial to success for small ventures.

To ascertain the extent to which small ventures relate to their employees, respondents were required to provide information on certain key labour issues. These included health care provision, absence of child labour, employee benefits, and freedom to choose amount of overtime.

The questions on the outcomes/benefits of BSR assessed expected or perceived as well as observed improvements in employee morale, employee turnover, employee productivity and customer loyalty as proxies to performance. As mentioned earlier, if executed well, BSR could lead to improved financial performance as a result of high employee 
morale, lower employee turnover, increased employee productivity and customer loyalty.

The questions on BSR awareness were intended to determine whether or not respondents were aware of the concept of BSR and its activities. If they were involved in BSR activities without being aware of the concept, it could probably be assumed that they did so for reasons other than to pursue BSR. If so, this would bring a different dimension to the BSR argument.

\section{Validity and reliability}

Underpinning all research endeavours is the question of credibility. The credibility of any research endeavour can only be achieved through a sound instrument. As pointed out by Cooper and Schindler (2001, p. 210), validity and reliability are two important characteristics of a sound instrument. Validity refers to the ability of a measuring instrument to measure what it intends to measure (Zikmund, 2003, p. 302). Steps were taken to ensure content and construct validity. Content validity, or face validity, of the measuring instrument is the extent to which the instrument provides adequate coverage of the concept. Content validity for this instrument was achieved by ensuring that the questionnaire items adequately cover the identified dimensions, elements and outcomes of the concept BSR as applied to small businesses according to our conceptualization of small business BSR. The items describing community involvement, employee relations, consumer relations, and outcomes covered the content "prescribed" by the BSR literature cited (and results from the preliminary instrument) and was summarised in accordance with Sekaran's (1992, p. 152) framework for operationally defining a concept so that it becomes measurable (see Figure 1).

According to Sekaran (1992, p. 173), construct validity refers to how well the results obtained from the use of the measure fit the theories on which the test is designed. A factor analysis was done to determine the internal consistency and thus reliability. A high Cronbach alpha, usually above 0.700 , is regarded as indicating reliability. Criterion validity could not be pursued because this requires availability of some "standard" that is known to indicate the construct adequately. Unfortunately such a universally recognised "standard" does not as yet exist for small business BSR measurement.

\section{Factor analysis}

An initial 80-item questionnaire was administered to 226 respondents. Exploratory factor analysis resulted in a final 31-item questionnaire. The second and final questionnaire was administered to 314 respondents. A second factor analysis, performed to confirm the homogeneity of the underlying constructs, resulted in the identification of the five factors, as shown in Tables IV and V

The factor analysis was conducted to verify whether the concepts of BSR represented distinct constructs. Exploratory factor analysis (with BMDP - Direct Oblimin) was applied to test specific propositions about the factor structure

\section{Table IV Classification matrix for sales growth}

Low sales growth $<10 \%$
Percentage
High sales growth $>10 \%$
Percentage
Total
Total correct for model

$\begin{array}{cc}155 & 113 \\ & 72.9 \\ 159 & 22 \\ & 23.8 \\ 314 & 135\end{array}$




\section{Table V Classification matrix for gross profit growth

\begin{tabular}{|c|c|c|c|c|}
\hline Alutial & Number of cases: & Low gross profit growth $(<10 \%)$ & High gross profit growth $(>10 \%)$ & Total \\
\hline Low gross profit growih & 158 & 117 & 41 & 158 \\
\hline Percenlage & & 74.1 & 26.6 & 100 \\
\hline High gross profil growith & 156 & 16 & 140 & 156 \\
\hline Percentage & & 10.3 & 89.7 & 100 \\
\hline Total & 314 & 133 & 181 & 314 \\
\hline Total correct for model & & 81.8 & & \\
\hline
\end{tabular}

for a set of variables. Items with low loadings and items with low internal correlations were eliminated. After rotation, the factor analysis suggested the existence of five factors. These factors were named as:

1. realised/actual benefits;

2. expected/perceived benefits;

3. community/customer practices;

4. BSR awareness/attitude; and

5. employee practices.

Oblique rotation was done because of the potential correlations between the factors that were expected.

\section{Factor structure and item analysis for the five factors}

The factor structure is shown in Table I. The means, standard deviations and other relevant statistics of the identified factors are shown in Tables II and III.

The high Cronbach alpha values indicate that the instrument did actually identify different factors of BSR. The factors that were identified explained 60.77 per cent (see Tables II and III) of the total variation in the sample. Based on the high Cronbach alpha values reported for the factors, the instrument seemed to have tested the intended constructs well.

Correlation analysis between factors indicates that significant correlations between factors exist (see also Tables II and III) suggesting that though the factors are different they are associated. Expected benefits and realised benefits were strongly correlated (0.587), while several moderate correlations were also observed. Despite the correlations, the factor analysis identified the five factors as independent factors explaining the variation.

\section{Discriminant analysis}

Stepwise discriminant analysis (BMDP, 1993, p. 369) was performed to determine how well the factors could classify a business as belonging to low sales growth or high sales growth categories, and high gross profit or low gross profit categories. Low growth was arbitrarily set at 10 per cent growth or below and high growth as over 10 per cent growth. Discriminant analysis as a statistical tool is normally used to classify a set of independent variables into two or more mutually exclusive categories. In other words, it is used to join a nominally scaled criterion (dependent variable) with one or more independent variables. In the current study, the factors: realised/actual benefits; expected/perceived benefits; community/customer practices; BSR awareness/attitude; and employee practices constitute the independent variables, with high growth/low growth in sales and profit as dependent variables. The statistical package BMDP 7M was used to perform the discriminant analysis that yielded results shown in Table IV. The statistical package BMDP 7M uses the general linear discriminant function:

$$
Z_{i}=a+b_{1} X_{1 i}+b_{2} X_{2 j}+\ldots+b_{n} X_{n i}
$$




$$
\begin{aligned}
& a=\text { constant; } \\
& x_{n i}=\text { the score on each predictor (independent variable): } \\
& b_{n}=\text { discriminant function coefficients (weights) for the independent variable; } \\
& Z_{i}=\text { discriminant score; and } \\
& n=\text { number of discriminating characteristics (factors) which in this case equals } 3 .
\end{aligned}
$$

The factors: expected benefits; realised/actual benefits; and employee practices, loaded as 'classification" variables for sales growth whilst BSR practices, and also loaded for gross profit growth. The results are shown in Tables IV and V. However, the factor Employee practice is the only one useful for prediction purpose.

Table IV indicates that the discriminant model predicted 72.9 per cent of the low sales growth correctly and 86.2 per cent of the high sales growth correctly based on employee practices. These figures are important and are explored in the discussion. Similarly, Table $V$ indicates that the model predicted 74.1 per cent of the low gross profit growth correctly and 89.7 per cent of the high profit growth correctly.

\section{Discussion of the findings}

Considering the results of the factor analysis, it seems that five factors (see also Tables IV and V) are associated with BSR in small business in the African context. The proposed instrument did measure BSR, given that it explains 60.77 per cent percent of the variation in the dataset. It further shows that BSR in small business is likely to be oriented towards employees, customers and the community, since these form their most important stakeholders.

The discriminant analysis, performed to determine how well the BSR factors could classify a business as belonging to either low or high sales growth and low or high gross profit growth categories, showed that expected benefits, realised benefits and employee practices are good "predictors" of a SMMEs performance. However, employee practice is the only usefu factor for performance prediction purposes. This ability to classify indicates that if one has nformation on a firm's employee practices, this information could be useful for predicting whether the company would record low or high gross profit or whether the company would record low or high sales.

It is interesting to note that the items constituting expected benefits (factor 1 ) are those with financial implications. This suggests that businesses get involved in BSR because of perceived link with profit (even if indirect), rather than for altruistic and humanistic reasons (see also future research).

The classification matrix for sales growth (Table IV) shows that the percentage of businesses correctly classified as low growth SMMEs was 72.9 per cent and those correctly classified as high growth SMMEs was 86.2 per cent. Overall, in terms of sales growth, the model correctly classified 79.6 per cent of the businesses. Similarly, the second classification matrix for gross profit growth (Table $\mathrm{V}$ ) shows that the percentage of those correctly classified as low growth SMMEs was 74.1 per cent and those correctly classified as high growth was 89.7 per cent. Overall, the model correctly classified 81.8 per cent of the businesses in terms of gross profit growth. Thus, the model predicts gross profit growth (81.8 per cent) somewhat better than sales growth (79.6 per cent).

Considering the fact that, if entirely left to chance, there is a 50 per cent chance of being correctly classified (since only two possibilities exist i.e. low or high), the classification power (79.6 per cent and 81.8 per cent) of the models appears quite high. These high levels of classification value support the idea that the constructs of the BSR instrument can be used to accurately classify venture performance as measured by sales growth and profit growth. Although three factors loaded as predictors, only one (employee practice) is really meaningful when using logistic regression for predicting sales growth and gross profit growth. This predictive value might find application in rating businesses for black economic empowerment in South Africa. This could be achieved by including BSR as a selection criterion for state tenders and preferential procurement strategies applied by governments.

\section{Value/usefulness of this study}

This study, as well as the emergent instrument, is intended to be useful for academics, managers of small businesses, and policy makers.

From a managerial point of view, the results that suggest positive financial benefits as a result of a small firm's involvement in BSR activities can be used to justify committing company resources to the pursuant of BSR. Although BSR activities may probably not result in direct financial benefits, the results of the discriminant analysis suggest that if BSR activities are present, financial performance as measured by sales and gross profit growth is better than when not present.

Secondly, as a result of this positive link, owner/managers might be encouraged to spend more on BSR expecting 
better business performance in return. Thus, at the heart of all these, it seems that BSR is about financial benefits for the implementer thereof and lends support to Henderson's (2004, p. 30) proposition that "the principal direct impulse to economic progress comes from profit related activities as it results from twin stimuli of increased entrepreneurial opportunities and competitive pressures". The results must however be seen in the context of 60.77 per cent variance that is explained by the constructs. It is therefore possible that other factors unknown to the research are playing a role.

Thirdly, the identified factors can help owner/managers of small businesses in selecting which BSR activities to focus their attention on. The high means reported for employee, customer, and local community issues means that these are important BSR issues for small businesses in the African context. This is probably because they form the most affordable BSR activities for small businesses given their resource limitations. From the point of view of those local small businesses that do not know which activities to engage in, this study highlights some affordable BSR activities. Similarly, international firms wanting to conduct business in Africa especially in the rural areas will now know where to focus their BSR activities.

From policy and practitioner point of view, the study makes it easier to sell BSR to business owner/managers because it could be argued that engaging in BSR has economic benefit. The reason is that, the higher than average means for realised benefits suggest that there is a definite relationship between economic benefit (profit) and BSR activities (although we did not show that it is causal in nature). The predictive value of the instrument might find application in rating businesses for black economic empowerment in South Africa. This could be achieved by using the SESRI as a selection criterion for state tenders and preferential procurement strategies applied by various levels of government.

From academic point of view, the identified factors in the SESRI give some direction to the underlying dimensions of BSR activities for small businesses. The high means reported for employee, customer, and local community issues suggest a strong focus on human aspects. It therefore seems that employee, customer, and local community issues are important BSR issues for small businesses in the African context. For academics, it means that these factors must never be ignored when pursuing BSR research agenda.

Secondly, the study points to the possibility of a causal relationship between firm performance and its BSR performance that can be explored further. Currently, there is no consensus about this relationship. The high levels of BSR awareness and performance with correspondingly high levels of financial performance is an indication of some positive relationship.

Thirdly, the identification of customer, community, and employee related activities as important BSR focus for small businesses in the current study is consistent with the findings of Byrd et al. (1994), Kyambalesa (1994), Longenecker et al. (2000), and Peyton (2003). This study therefore helps in the validation of other findings.

Finally but not the least, the emergent instrument provides a means of measuring BSR in small businesses specifically in the African context.

\section{Limitations of the study}

As in all research endeavours, our study is not devoid of limitations. There are some imitations in the current study that should be considered when generalising the validity of the instrument.

Firstly, we acknowledge that self-evaluation by respondents pose certain limitations. For example, critiques might cite self-serving bias as a threat to the results. However, respondents who reported low levels of BSR activities (and negative growth in sales and performance) also reflected on their own "performance" and recorded it as low, signifying some level of realistic reporting. We are therefore inclined to believe that, despite the potential for selfreporting bias, this threat was minimal and could be ignored. The results are therefore useful to guide owners and managers in selection of BSR practices.

A second limitation is the absence of question items about environmental issues such as waste dumping, biosphere protection and more activities that are typically associated with large industrial ventures. These were not included as they did not appear as issues during the first round investigation where open-ended questions were used to identify constructs. It is proposed that the instrument be improved before it is used in further research.

Thirdly, since the data was collected from a sample drawn from a small rural setting, there is need for caution when generalising from the results. Therefore, the results can only be generalized to rural South African settings. Still, we argue that there is a convergence in the needs of most African rural areas to the extent that a scale developed in South Africa can provide insight into the understanding of BSR in other African rural settings especially in sub-Saharan African countries. 
The study points to some future research issues. Firstly, we did not investigate why the businesses get involved in BSR. There is the likelihood that some or most get involved in BSR because of perceived economic benefits, rather than for altruistic and humanistic reasons. It is suggested that future research should investigate what motivates businesses to pursue BSR. Secondly, are there any moderating factors such as race, gender, business size, stage of life cycle and business experience, which may affect the outcome of the different factors that were identified? Thirdly, leading from the above question, we ask: What is the relationship between "ubuntu" and BSR? Could it be that the inherent cultural belief in caring for others in the community has a relation to what is defined as BSR in this study? This would suggest culture as a moderating factor. Finally it is interesting to note that although we did not include environmental issues in our questionnaire, no respondent mentioned environmental issues even when given the opportunity to mention any

other BSR related issues that they thought should be considered. Does this mean environmentalism is a contextual issue that is not associated with SMMEs?

\section{Conclusion}

The primary objective of this study was to use the dimensions, elements, and outcomes of BSR relevant for small ventures from the literature to construct and test the SESRI for measuring BSR in the African venture setting. This was achieved despite the limitations identified. The results show that the measurement instrument did measure the concept BSR in small ventures as it intended at its outset. There was benefit in the process of using first round open questions and a questionnaire before the final instrument was completed.

The secondary objectives were to aid small businesses in Africa in the selection of BSR best practices and to facilitate greater understanding of the concept of BSR. The results show some awareness of the elements associated with BSR but opened the question of why businesses pursue these practices. The higher than average means for expected benefits suggest owners/managers are aware of the benefits associated with BSR activities.

Finally, there is a definite relation between economic benefit (profit) and BSR activities. Thus, from a practitioner point of view, this makes it easier to sell BSR to business owner/because it could be argued that BSR practice has economic benefit.

\section{References}

Aupperle, K.E. (1984), "An empirical measure of corporate social orientation", in Preston, L.E. (Ed.), Research in Corporate Social Performance and Policy, Vol. 6, JAI, Greenwich, CT, pp. 27-54.

Baskin, J. (2005), "Corporate social responsibility practices of emerging market companies: a fact finding study", OECD working paper on international investment, No. 2005/3, OECD, Paris.

Baucus, M.S. and Baucus, D.A. (1997), "Paying the Piper: An Empirical Investigation of long-term financial consequences of illegal corporate behaviour", Academy of Management Journal, Vol. 40 No. 1, pp. 129-51.

BMDP (1993), in Dixon, W.J. (Ed.), BMDP Statistical Software Manual, Vol. 1.

Bragdon, J.H. and Marlin, J.A. (1972), "Is pollution profitable?", Risk Management, Vol. 19, pp. 9-18.

Business for Social Responsibility (2001), "Introduction to corporate social responsibility", available at www.bsr.org/BSRResourcesAWhitePaper

Byrd, M.J., Megginson, L.C. and Megginson, W.L. (1994), Small Business Management: An Entrepreneur's Guide to Success, Richard D. Irwin Inc., Boston, MA.

Carroll, A.B. (1979), "A three-dimensional conceptual model of corporate performance", Academy of Management Review, Vol. 4, pp. 497-505.

Centre of Strategic Research and Development of Georgia (2007), Large Business in Tbilisi and Corporate Social Responsibility Attitude and Practice, CSRDG, Tbilisi.

Chen, K.H. and Metcalf, R.W. (1984), "The relationship between pollution control record and financial indicators revisited", The Accounting Review., Vol. 55, pp. 168-77.

Cooper, D.R. and Schindler, PS. (2001), Business Research Methods, 7th ed., McGraw-Hill, Boston, MA.

Davidson, W.N. and Worrell, D.L. (1990), "A comparison and test of the use of accounting and stock market data m relating corporate social responsibility and financial performance", Akron Business and Economic Review, Vol. 21, pp. 7-19.

Davis, K. (1973), "The case for and against business assumption of social responsibilities", Academy of Management Journal., Vol. 16 No. 2, pp. 312-22. 
Donaldson, T. and Preston, L.E. (1995), "The stakeholder theory of the corporation: concepts, evidence, and implications", Academy of Management Review, Vol. 20 No. 1, pp. 65-91.

Dzansi, D.Y. (2004), Pretoria, "Social responsibility of SMMEs in rural communities", unpublished PhD thesis, University of Pretoria, Pretoria.

Freedman, N. and Jaggi, B. (1982), "Pollution disclosures, pollution performance, and economic performance", The International Journal of Management Science, Vol. 10, pp. 167-76.

Henderson, D. (2004), "An apology for capitalism", paper presented at the Stockholm Network/Economist Conference, Friday 20 February 2004, available at: www.stockholm-network.org/_downloads/events/d41 d8cd9-David7o20Henderson.doc

Holme, R. and Watts, P. (2000), Corporate Social Responsibility: Making Good Business Sense, WBCSD, Geneva.

Irwin, R. (2003), "Corporate social investment and branding in the new South Africa", Journal of Brand Management, Vol. 10 Nos 4/5, pp. 303-8.

Kapelus, P. (2007), in Visser, W., Matten, D., Pohl, M. and Tolhurst, N. (Eds), The A to Z of Corporate Social Responsibility, John Wiley, Chichester.

Kyambalesa, H. (1994), Success in Managing a Small Business, Avebury, Ashgate.

Laczniak, G.R. and Murphy, PE. (1993), Ethical Marketing Decisions: The Higher Road, Allyn \& Bacon, Boston, MA.

Longenecker, J.G., Moore, C.W. and Petty, J.W. (2000), Small Business Management: An Entrepreneurial Emphasis, 11th ed., SouthWestern College Publishing, Cincinnati, $\mathrm{OH}$.

McGuire, J.W. (1963), Business and Society, McGraw-Hill, New York, NY.

Maigan, I. and Ferrell, O.C. (2000), "Measuring corporate citizenship in two countries: the case of the United States and France", Journal of Business Ethics, Vol. 23 No. 3, pp. 283-97.

Peyton, K. (2003), CSR: Who Needs It?, available at www.cbsr.bc.ca (accessed 29 March 2003).

Quazi, A.M. and O'Brien, D. (2000), "An empirical test of a cross-national model of corporate social responsibility", Journal of Business Ethics, Vol. 25, pp. 33-51.

Ruf, B.M., Muralidhar, K. and Paul, K. (1998), "The development of a systematic, aggregate measure of corporate social performance", Journal of Management, Vol. 24 No. 1, pp. 119-33.

Sekaran, U. (1992), Research Methods for Business: A Skill Building Approach, 2nd ed., Wiley, New York, NY.

Sims, R.R. (2003), Ethics and Corporate Social Responsibility: Why Giants Fall, Praeger, New York, NY.

Turker, D. (2009), "Measuring corporate social responsibility: a scale development study", Journal of Business Ethics, Vol. 85 No. 4 , pp. 411-27.

Visser, W. (2007), "Corporate social responsibility in developing countries", in Matten, D., Moon, J. and Siegel, D.A. (Eds), The Oxford Handbook of Corporate Social Responsibility, Oxford University Press, Oxford, pp. 473-99.

Welford, R. (2005), "Corporate social responsibility in Europe, North America and Asia: 2004 survey results", The Journal of Corporate Citizenship, Vol. 17, pp. 33-52.

Weyzig, F. (2006), "Local and global dimensions of corporate social responsibility in Mexico", The Journal of Corporate Citizenship, Vol. 24, pp. 69-81.

Wingard, H.C. (2001), "Financial performance of environmentally responsible South African Listed companies", PhD thesis, University of Pretoria, Pretoria.

World Business Council for Sustainable Development (WBCSD) (2003), Corporate Social Responsibility: Making Good Business Sense, WBCSD, Washington, DC, available at www.wbscd.org. (accessed 21 March 2003).

Zikmund, W.G. (2003), Business Research Methods, 7th ed., South-West Publishers.

\section{Further reading}

Birch, D. and Littlewood, G. (2004), "Corporate citizenship: some perspectives from Australian CEO's", Journal of Corporate Citizenship., Vol. 16, pp. 61-9.

Bird, F. and Smucker, J. (2006), "The social responsibilities of international business firms in developing areas", Journal of Business Ethics, Vol. 73 No. 1, pp. 1-9.

DeCleene, S. and Sonnenburg, D. (2004), Socially Responsible Investment in South Africa, 2nd ed., African Institute of Corporate Citizenship, Johannesburg. 


\section{About the authors}

Dennis Yao Dzansi, PhD (Entrepreneurship); MBA; MA (Higher Education Studies), is the Program Head for the BTech Degree in Project Management and a Senior Lecturer in various management subjects based at the School of Entrepreneurship and Business Development, Faculty of Management Science, Central University of Technology, Bloemfontein, South Africa. Dennis Yao Dzansi is the corresponding author and can be contacted at: ddzansi@cut.ac.za

Marius Pretorius, DTech (Business Administration), Master of Business Leadership, MSc Agric, BSc Hons Agriculture is Associate Professor in Strategy and Leadership based at the Department of Business Management, University of Pretoria, South Africa. 